\title{
Do benthic meiofaunal and macrofaunal communities respond to seasonality in pelagial processes in an Arctic fjord (Kongsfjorden, Spitsbergen)?
}

\author{
Maria Włodarska-Kowalczuk ${ }^{1}$ - Barbara Górska ${ }^{1}$. \\ Kajetan Deja ${ }^{1} \cdot$ Nathalie Morata ${ }^{2,3}$
}

Received: 1 December 2015/Revised: 7 May 2016/Accepted: 23 May 2016/Published online: 17 June 2016

(c) The Author(s) 2016. This article is published with open access at Springerlink.com

\begin{abstract}
This study explores whether the marked seasonality in pelagic productivity and phytodetritus fluxes to the sea bottom in an Arctic fjord is reflected in variability of benthic communities in terms of taxonomic composition and standing stocks. Three stations located along the Kongsfjorden (west Spitsbergen) axis were visited in four seasons (May, August, October and January), and meiofauna and macrofauna was sampled. The elusive seasonal variability in benthic attributes contrasted with the clear seasonal effects in organic matter productivity and vertical fluxes (with diatom bloom-related peak in spring). No consistent differences in meiofaunal and macrofaunal density, diversity or composition among the four seasons were detected by PERMANOVA tests. Possible responses to spring food supply in meiofaunal reproduction timing were demonstrated in variability in individual size of Nematoda (decline in October after the maximum in August), Harpacticoida (decline in May and increase till October) and macrobenthic Crustacea (minimum in May). The spatial patterns shaped by the environmental gradients related to glacial inputs, the faunal impoverishment in
\end{abstract}

This article belongs to the special issue on the "Kongsfjorden ecosystem-new views after more than a decade of research", coordinated by Christian Wiencke and Haakon Hop.

Maria Włodarska-Kowalczuk

maria@iopan.gda.pl

1 Institute of Oceanology Polish Academy of Sciences, Powstańców Warszawy 55, 81-712 Sopot, Poland

2 Laboratoire des Sciences de L'environnement Marin Sciences (LEMAR), CNRS UMR 6539, University of Brest, Rue Dumont D’Urville, 29280 Plouzané, France

3 Akvaplan-niva, Fram Centre for Climate and the Environment, N-9296 Tromsö, Norway inner basin and a shift in dominants along the fjord axis, were clearly designated and stable throughout the year. The resilience of Arctic fjordic benthic community to marked seasonality in pelagic phytodetritus fluxes may be related to organic matter reserves in sediments (large enough to sustain the detritus feeders on a year-round basis), inclusion of macroalgal carbon into the diet and common employment of lecithotrophic larva or direct development by polar benthos.

Keywords Seasonality - Meiofauna - Macrofauna Diversity $\cdot$ Biomass $\cdot$ Arctic fjords

\section{Introduction}

Marine biological productivity in the Arctic is highly constrained by the light availability (determined by solar angle) and ice presence and thickness, which undergo marked seasonal cycles (Wassmann and Reigstad 2011; Berge et al. 2015). In the open ocean, organic matter is produced by phytoplankton and ice algae. The ice algal bloom takes place under consolidated ice in early spring, with the phytoplankton in the water column, weeks to months later after ice break-up (Søreide et al. 2013). The timing of ice algae and phytoplankton production at the base of the food web is vital for the quantity and quality of biomass production, and for the transfer of energy to higher trophic levels, as the trophic pathways of energy in this system are strongly controlled by zooplankton grazing (Søreide et al. 2013). In general, several Arctic studies report elevated fluxes of organic matter to the seafloor (in terms of quantity and quality of organic matter, indicated by POC and chlorophyll $a$ content, respectively) in spring compared to the other seasons (Lalande et al. 2016; Juul- 
Pedersen et al. 2008; Reigstad et al. 2008; Zajączkowski et al. 2010).

In Arctic shelf seas, pelagic-benthic coupling is regarded to be particularly 'tight,' i.e., the variability in benthic stocks and processes are tightly linked to pelagic production and vertical fluxes that was demonstrated in largescale studies of spatial variability of benthic communities of Arctic shelf seas (e.g., Grebmeier et al. 1988). The Arctic reports of benthic responses to seasonal fluxes of organic matter from water column detected on a temporal scale usually refer to a rise in sediment community respiration rates. Such effects were documented after the seasonal pulse of organic matter sedimentation in the Beaufort Sea (Renaud et al. 2007; Link et al. 2011), in the Barents Sea (Renaud et al. 2008) and in Greenland fjords (Rysgaard et al. 1998). However, signals of seasonal increase in sediment respiration do not necessarily indicate a similar rise in the standing stocks or activity of meiobenthic or macrobenthic communities. Rysgaard et al. (1998) attributed the most-observed effects of seasonal increases in sediment oxygen uptake in Greenland fjords to the microbial activities within surface sediments. Piepenburg et al. (1995) estimated that in subtidal fine-grained Barents Sea sediments, macrofauna only contributes $25 \%$ and meiofauna $<10 \%$ to the total oxygen uptake. The bacteria, meiofauna and macrofauna of benthic communities may respond differently to environmental impacts as reported for meiofauna and macrofauna subjected to sediment disturbance (Austen et al. 1989; Warwick et al. 1990) or for bacteria, meiofauna and macrofauna response to seasonality in environmental fluctuations in large rivers estuaries (Aller and Stupakoff 1996). The few Arctic seasonal studies that included analyses of sediment respiration and macrobenthic biomass reported that a rise in sediment oxygen uptake after the seasonal pulse of organic matter to the sea floor was not accompanied by an increase in macrobenthic biomass (Renaud et al. 2008; Link et al. 2011). Moreover, the results in the few studies on seasonal variability in polar benthos standing stocks and taxonomic composition are equivocal, often reporting no or little seasonal effects (Echeverria and Paiva 2006; Kędra et al. 2012).

Ongoing climate change is expected to lead to changes in the sea ice regime, light penetration, water mass distribution and stratification that will have repercussions on primary productivity in Arctic seas (Wassmann and Reigstad 2011). However, the consequences for energy flow, vertical fluxes and benthic communities remain uncertain. The seasonal variability and the responses of benthic community standing stocks and composition (that define the basic constrains of the community functioning) to strong seasonality of pelagial and ice algae carbon supply to the seabed remain little understood which impedes the predictions of the effects of the future changes. In 2012-2013, a comprehensive program of seasonal observations of pelagic and benthic systems was undertaken in one of the Arctic (west Spitsbergen) fjords, Kongsfjorden. The first reports documented clear seasonal variability in pelagial productivity (Calleja et al. unpublished data) and organic matter vertical fluxes to the bottom (Lalande et al. 2016), with little seasonal change in organic matter content in surface sediments (Bourgeois et al. unpublished data). Here we explore whether the marked seasonality in pelagic processes is reflected in variability of benthic meio- and macrofaunal communities in terms of diversity, taxonomic composition and standing stocks.

\section{Methods}

\section{Study area}

Kongsfjorden $\left(79^{\circ} \mathrm{N}\right.$ and $\left.12^{\circ} \mathrm{E}\right)$ is located on the northwest part of Spitsbergen Island in the Svalbard archipelago (Fig. 1). This fjord is oriented from southeast to northwest, $27 \mathrm{~km}$ long and $10 \mathrm{~km}$ wide at its entrance. The physical settings and biological characteristics of the fjord are reviewed by Svendsen et al. (2002) and Hop et al. (2002). Kongsfjorden receives warm and cold water inflows from the Atlantic and Arctic currents, respectively (Svendsen et al. 2002), as well as freshwater inflow from four tidal glaciers, in particular Kongsbreen $\left(105 \mathrm{~km}^{2}\right)$ highly affecting the inner part of the fjord (Svendsen et al. 2002). Whereas Kongsfjorden used to be seasonally ice-covered, it has remained ice-free since 2006 following a major inflow of warm Atlantic water into the fjord during the winter of 2005-2006 (Cottier et al. 2007). The two fjord basins are separated by the shallows of Lovennoyane, the sea bottom in both basins is covered with homogenous mud (Włodarska-Kowalczuk and Pearson 2004), while the sediment accumulation rate decreases from $20,000 \mathrm{~g} \mathrm{~m}^{-2}$ year $^{-1}$ in the inner basin to $200 \mathrm{~g} \mathrm{~m}^{-2}$ year $^{-1}$ at the fjord entrance (Svendsen et al. 2002).

In 2012-2013, ECOTAB project undertook the comprehensive survey of seasonal and spatial variability of environmental settings in Kongsfjorden, water column and sediments. In four seasons (May, August, October and January), three stations were studied. The inner station (station A) was located at $1.4 \mathrm{~km}$ from head of the fjord, under the direct influence of the tidal glacier inputs. The middle station (station B) was located midway between the tidal glacier and the ocean. The outer station (station C) was located near the fjord mouth (Fig. 1; Table 1). Calleja et al. (unpublished data) and Lalande et al. (2016) documented a strong seasonal variation in water column processes. They show that in spring, a massive diatom bloom 
Fig. 1 Location of sampling stations in Kongsfjorden

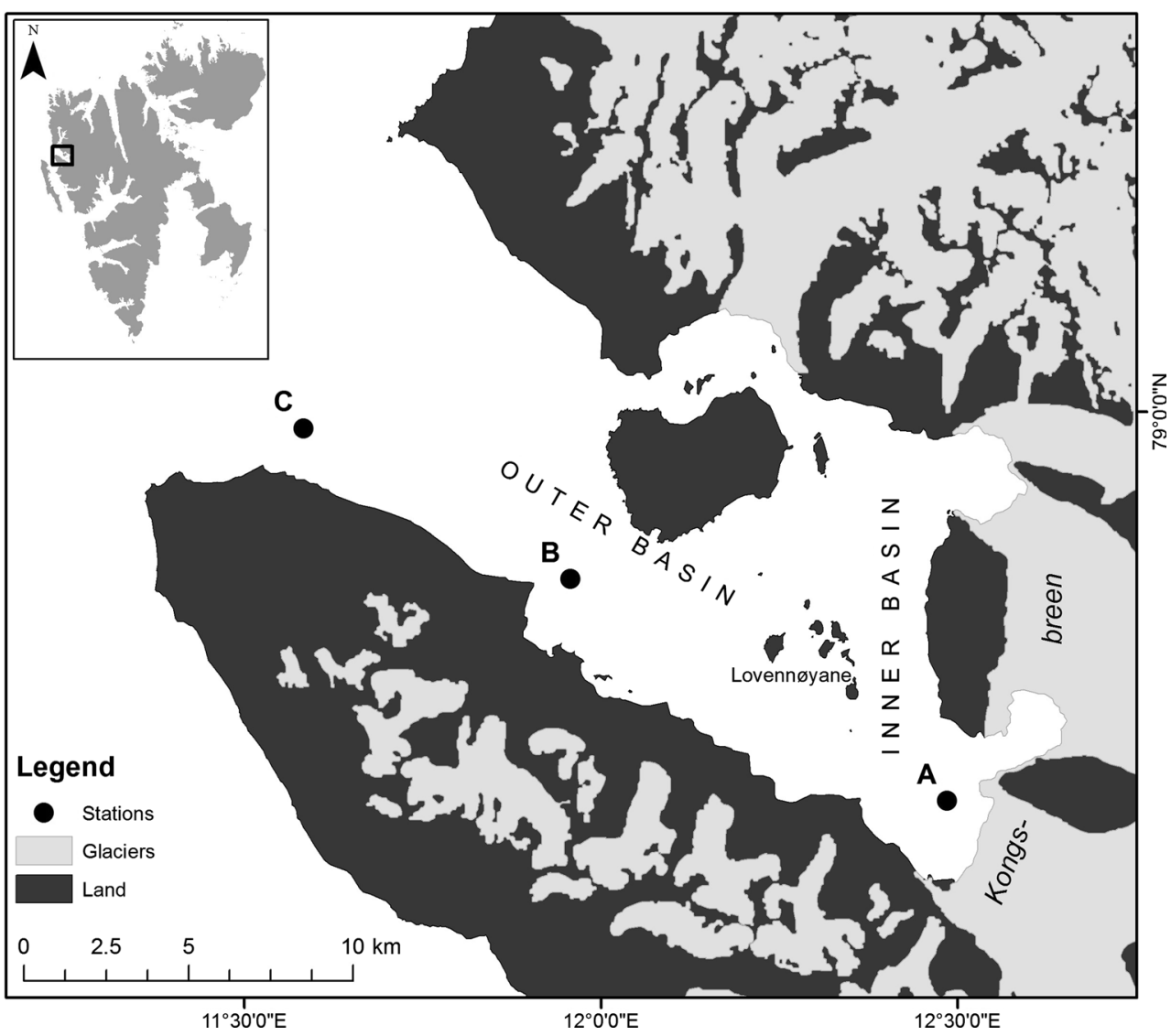

Table 1 Positions, depths and environmental characteristics at stations

\begin{tabular}{|c|c|c|c|}
\hline & Station A & Station B & Station C \\
\hline Position & $78^{\circ} 53.53 \mathrm{~N}, 12^{\circ} 28.41 \mathrm{E}$ & $78^{\circ} 56.86 \mathrm{~N}, 11^{\circ} 55.59 \mathrm{E}$ & $78^{\circ} 59.07 \mathrm{~N}, 11^{\circ} 32.14 \mathrm{E}$ \\
\hline Depth (m) & 80 & 295 & 305 \\
\hline Bottom water temperature $\left({ }^{\circ} \mathrm{C}\right)^{\mathrm{a}}$ & $2.64 \pm 0.72(1.7-3.4)$ & $2.51 \pm 0.57(1.8-3.2)$ & $2.73 \pm 0.43(2.2-3.0)$ \\
\hline Bottom water salinity ${ }^{a}$ & $\begin{array}{l}34.70 \pm 0.15 \\
(34.58-34.91)\end{array}$ & $\begin{array}{l}34.94 \pm 0.07 \\
(34.84-34.99)\end{array}$ & $\begin{array}{l}34.94 \pm 0.07 \\
(34.83-34.99)\end{array}$ \\
\hline Chlorophyll $a$ in surface sediments ${ }^{\mathrm{b}}\left(\mathrm{mg} \mathrm{m}^{-2}\right)$ & $\begin{array}{r}18.31 \pm 15.36 \\
(1.61-41.78)\end{array}$ & $\begin{array}{l}14.56 \pm 4.53 \\
(6.79-19.34)\end{array}$ & $\begin{array}{l}13.18 \pm 9.41 \\
(5.31-16.31)\end{array}$ \\
\hline Chlorophyll $a$ /pheopigments in surface sediments ${ }^{\mathrm{b}}$ & $0.37 \pm 0.2(0.11-0.60)$ & $0.18 \pm 0.05(0.09-0.24)$ & $0.18 \pm 0.06(1.59-1.74)$ \\
\hline POC in surface sediments ${ }^{b}(\%$ DW) & $0.27 \pm 0.06(0.21-0.36)$ & $1.07 \pm 0.15(0.79-1.27)$ & $1.68 \pm 0.05(1.59-1.74)$ \\
\hline $\begin{array}{l}\text { Concentration of mineral suspensions in surface waters } \\
\left(\mathrm{mg} \mathrm{dm}^{-3}\right)\end{array}$ & 275 & 25 & 20 \\
\hline Sediment accumulation rate ${ }^{\mathrm{d}}\left(\mathrm{g} \mathrm{m}^{-2} \mathrm{a}^{-1}\right)$ & 20,000 & 1800 & 200 \\
\hline
\end{tabular}

Mean \pm SD and min-max (in parentheses) are presented

Based on ECOTAB data [ ${ }^{\mathrm{a}}$ Calleja et al. (unpublished data) $]$ and ${ }^{\mathrm{b}}$ Bourgeois et al. (unpublished data) and other published studies from Kongsfjorden ( ${ }^{c}$ Zajączkowski 2008, d Svendsen et al. 2002)

occurred, which was reflected in elevated export fluxes of algal biomass to the seafloor. In summer and fall, the relative contributions of diatoms decreased and were replaced by Dinoflagellata. Vertical fluxes of algal biomass also decreased in other seasons. Only the export fluxes of total particulate matter remained high at the inner station in summer, because of the melting of glacier due to the release of particulate matter associated with the glacier melt. Surprisingly, despite the seasonal change in water column processes, Bourgeois et al. (unpublished data) documented a predominance of the spatial variability over temporal variability in sediment organic matter, due to the 
strong glacier influence. The particulate organic carbon content in sediments decrease from about $1.5 \%$ in the outer basin to below $0.5 \%$ in the inner basin (Bourgeois et al. unpublished data; Włodarska-Kowalczuk and Pearson 2004; Kuliński et al. 2014).

\section{Sampling, laboratory and data analyses}

Materials were collected at the three stations located along the fjord axis (Fig. 1; Table 1). Sampling took place in four seasons in 2012-2013: spring (May 18-26, 2012), summer (August 1-9, 2012), autumn (October 2-13, 2012) and winter (January 8-19, 2013). The material was collected from board of $r / v$ 'Oceania' (summer) and $r / v$ 'Teistein' (other seasons). At each station/in each season, 3 replicate samples for macrofauna (with use of the van Veen grab, $0.1 \mathrm{~m}^{2}$ catching area) and 3 replicate samples for meiofauna (with use of the box-corer and a plastic syringe of $3.57 \mathrm{~cm}$ diameter (i.e., $10 \mathrm{~cm}^{2}$ sampling area) inserted $5 \mathrm{~cm}$ into the box) were collected. In October and January, sampling was not conducted at station A due to navigational constraints. Samples for macrofauna were sieved on board through a $0.5-\mathrm{mm}$ sieve. Macrofauna and meiofauna samples were fixed in a $4 \%$ formaldehyde solution in seawater.

In the laboratory, macrofauna samples were counted and identified to the possible lowest taxonomic level. Wet weights of macrofaunal taxa in samples were assessed with use of laboratory balance. Meiobenthic samples were centrifuged three times in a solution of colloidal silica (Ludox TM-50) with a density of $1.18 \mathrm{~g} \mathrm{~cm}^{-3}$ and stained in $4 \%$ buffered formaldehyde solution with Rose Bengal (Heip et al. 1985). All invertebrates that passed through a $0.5-\mathrm{mm}$ sieve and were retained on a $32-\mu \mathrm{m}$ sieve, were counted, identified to the major taxa level and photographed with camera connected to stereomicroscope. For each specimen, total length and width were measured using digital image analysis. Only for the Nematoda, a random subsample of 100 individuals from each sample was measured using the semiautomated method of image analyses (Mazurkiewicz et al. in press). Nematodes' wet weight was estimated using Andrassy's formula (Andrassy 1956). For the other meiofaunal taxa, the volume was calculated with Feller and Warwick's (1988) formula: $V=L \cdot W^{2} \cdot \mathrm{c}$, where $(V)$ is the volume, $(L)$ is the max body length, $(W)$ is the width, and $(c)$ is the taxon-specific coefficient. Wet weight was estimated using the equation: $\mathrm{WW}$ (wet weight) $=1.13 \cdot \mathrm{V}$.

Species (taxonomic) richness, defined as the number of taxa in a sample $(S)$, species diversity measured with the Shannon-Wiener diversity $\log _{\mathrm{e}}$-based index $(H)$ and evenness of distribution of individuals among taxa expressed by the Pielou index $(J)$ were calculated for all meio- and macrobenthic samples. Individual biomass (IB, wet biomass estimated for 100 individuals in each samples based on dimensions measurements) was analyzed for two dominant meiofaunal groups: Nematoda and Harpacticoida. Average individual biomass ( $A I B$, calculated as biomass divided by abundance) was assessed for dominant macrofaunal higher taxa (Polychaeta, Mollusca, Crustacea) and polychaete families (Cirratulidae, Lumbrineridae, Oweniidae, Sabellidae, Spionidae, Maldanidae). Differences in univariate characteristics (density, $S, J, H$, biomass, nematode and harpacticoid $I B$ and macrofaunal taxa $A I B$ ) among the three stations (A, B and C) and four seasons (May, August, October and January) were tested using the two-way PERMANOVA model based on a similarity matrix created from the Euclidean distances among samples. When a significant effect of a factor $(p<0.05)$ was indicated by a main test, pairwise post hoc comparisons were performed. When both a significant effect of a factor and significant interaction between two factors (station and season) were detected, pairwise tests for differences between different levels of a factor were performed separately within each level of the other factor, as recommended by Anderson et al. (2008).

Bray-Curtis similarities were calculated for meiobenthic higher taxa and macrobenthic species abundances in the samples. The data were square-root-transformed, and meiofaunal data were additionally standardized (prior to transformation) to eliminate the effect of the very high variability of the total abundances in samples. The patterns of meiobenthic and macrobenthic composition were illustrated with PCO (principal coordinates analysis) ordinations. In addition, PCO ordination was plotted for macrofaunal samples collected at stations $\mathrm{B}$ and $\mathrm{C}$ to explore the patterns of variability in the central basin. The two-way PERMANOVA models (with two fixed factorsseason and station) were applied to the similarity matrices. Both main tests and post hoc pairwise comparisons were performed.

Relationships between environmental variables and meiobenthic and macrobenthic density, biomass, species richness and community composition were investigated using the distance-based linear models (DISTLM) procedure in PERMANOVA+ (Anderson et al. 2008). The environmental data were collected at the same station/ sampling dates as the benthic samples. The data have been provided by Calleja et al. (unpublished data), Lalande et al. (2016) and Bourgeois et al. (unpublished data). The dataset of six environmental variables was used for the analyses: total suspended matter and chlorophyll $a$ concentration at depth of maximum fluorescence in water column, temperature and salinity of near-bottom waters, POC and chlorophyll $a$ concentration in surface (upper $2 \mathrm{~cm}$ ) sediments. Four factors were also available but were excluded 
Table 2 Frequency of occurrence $[F(\%)]$, dominance $[D(\%)]$ and mean density $[a v D$ (ind. $10 \mathrm{~cm}^{-2}$ )] of meiofaunal taxa in groups of samples collected at the three stations (A, B, C)

\begin{tabular}{|c|c|c|c|c|c|c|c|c|c|}
\hline & \multicolumn{3}{|c|}{ Station A } & \multicolumn{3}{|c|}{ Station B } & \multicolumn{3}{|c|}{ Station C } \\
\hline & $F$ & $D$ & $a v D$ & $F$ & $D$ & $a v D$ & $F$ & $D$ & $a v D$ \\
\hline Nematoda & 100 & 94.4 & 246.1 & 100 & 97.0 & 3319.9 & 100 & 94.6 & 1371.3 \\
\hline Polychaeta & 56 & 1.2 & 3.2 & 100 & 0.9 & 30.8 & 100 & 1.2 & 16.6 \\
\hline nauplii Copepoda & 11 & 0.4 & 1.0 & 100 & 0.5 & 18.8 & 75 & 0.8 & 11.2 \\
\hline Kinorhyncha & 22 & 0.4 & 1.0 & 92 & 0.4 & 14.3 & 83 & 0.9 & 12.8 \\
\hline Bivalvia & 33 & 0.4 & 1.0 & 67 & 0.1 & 1.9 & 42 & 0.2 & 3.4 \\
\hline Harpacticoida & 11 & 0.8 & 2.0 & 100 & 0.6 & 19.3 & 92 & 1.2 & 18.0 \\
\hline nauplii Cirripedia & 11 & 0.4 & 1.0 & 83 & 0.2 & 6.0 & 75 & 0.6 & 7.9 \\
\hline Tanaidacea & - & - & - & 17 & 0.0 & 1.0 & 42 & 0.1 & 1.0 \\
\hline Ostracoda & - & - & - & 58 & 0.1 & 2.0 & 42 & 0.2 & 2.2 \\
\hline Turbellaria & 22 & 1.2 & 3.0 & 33 & 0.0 & 1.3 & 25 & 0.1 & 1.0 \\
\hline Priapulida & - & - & - & 8 & 0.0 & 1.0 & - & - & - \\
\hline Rotifera & 33 & 0.5 & 1.3 & 8 & 0.0 & 2.0 & 17 & 0.1 & 1.0 \\
\hline Acarina & 33 & 0.4 & 1.0 & 17 & 0.0 & 1.5 & 8 & 0.1 & 1.0 \\
\hline Cnidaria & - & - & - & 8 & 0.0 & 1.0 & 8 & 0.1 & 1.0 \\
\hline Priapulida larva & - & - & - & 58 & 0.1 & 1.7 & 8 & 0.1 & 1.0 \\
\hline
\end{tabular}

from further analyses due to strong intercorrelation in the dataset (Pearson correlation $>0.85$ ): average total suspended mater, maximum fluorescence in water column, total organic carbon and chlorophyll $a$ /pheopigments ratio in surface sediments. Both marginal (all factors treated independently) and sequential (factors added stepwise to a model, and only an 'added effect' considered) tests were performed. In sequential test, the forward selection procedure based on adjusted $R^{2}$ as a selection criterion was used to determine the best combination of predictor variables. This procedure first chooses the variable with the best value of the selection criterion and then follows with selecting the next variable that together with the first one improves the selection criterion the best and so on. The procedure stops when no further improvement in the selection criterion is possible (Anderson et al. 2008). In the statistical analyses results, effects with $p<0.05$ are treated as significant, $p s F$ stands for pseudoF statistics.

\section{Results}

\section{Meiofauna}

Fifteen meiofaunal taxa were identified. Meiofauna was dominated by Nematoda in terms of abundance (on average $96 \%$ of all individuals in samples) and biomass (68\%), followed by Harpacticoida ( 1 and $5 \%$, respectively) and Polychaeta (1 and $20 \%$ ).

Only 10 taxa were found in samples collected at station A (Table 2). Nematodes occurred with a mean density of 246 ind. $10 \mathrm{~cm}^{-2}$ and made $94 \%$ of all collected individuals (71 \% of the meiofaunal biomass). They were also the only taxon that occurred within more than $75 \%$ of samples. The other taxa that made relatively high numbers in the glacial bay-Polychaeta, Turbellaria (3 ind. $10 \mathrm{~cm}^{-2}$ on average) and Harpacticoida (2 ind. $10 \mathrm{~cm}^{-2}$ )_occurred with a frequency of 56, 22 and $11 \%$, respectively. All taxa were present at stations B and C. Four taxa occurred in $100 \%$ samples and 3 more taxa in 67-92\% of samples collected at station B. At station C, two taxa occurred in all samples, and further 4 taxa occurred in 75-92\% of samples. Besides nematodes (mean density over 3000 ind. $10 \mathrm{~cm}^{-2}$ at station $\mathrm{B}$ and over 1300 ind. $10 \mathrm{~cm}^{-2}$ at station C), Polychaeta (31 and 17 ind. $10 \mathrm{~cm}^{-2}$, respectively), Harpacticoida (19 and 18 ind. $\left.10 \mathrm{~cm}^{-2}\right)$ and nauplii Copepoda (19 and 11 ind. $10 \mathrm{~cm}^{-2}$ ) occurred with large numbers of individuals at these two stations.

Significant differences between stations but no seasonal effect in density and taxonomic richness were identified by PERMANOVA main test (Table 3). Density was the lowest at station A (ranged from 11 to 757 ind. $10 \mathrm{~cm}^{-2}$ ) and highest at station B (from 877 to 5172 ind. $10 \mathrm{~cm}^{-2}$, Fig. 2). Number of taxa was significantly lower at station $A$ (2-5 taxa per sample) than at the other two stations (5-12 taxa per sample) with no differences between station $\mathrm{B}$ and station $\mathrm{C}$ detected by post hoc pairwise tests. No effects of either station or season were found for Shannon-Wiener index of diversity or Pielou index of evenness. Total meiofauna biomass varied from $0.01 \mathrm{mg} 10 \mathrm{~cm}^{-2}$ (station A in August) to $5.14 \mathrm{mg} 10 \mathrm{~cm}^{-2}$ (station B in August). Significant differences in total meiofauna biomass between groups of samples defined by station and season as well as 
Table 3 Results of two-way PERMANOVA tests for differences in meio- and macrobenthic univariate [biomass, density, number of taxa per sample $(S)$, Shannon-Wiener index $(H)$, and Pielou index $(J)]$ and multivariate (comp-Bray-Curtis similarity) characteristics among stations (St) and seasons (Se)

\begin{tabular}{|c|c|c|c|c|c|c|c|c|c|c|c|c|c|}
\hline \multirow[t]{2}{*}{ Source } & \multirow[t]{2}{*}{$d f$} & \multicolumn{2}{|c|}{ Biomass } & \multicolumn{2}{|c|}{ Density } & \multicolumn{2}{|l|}{$S$} & \multicolumn{2}{|l|}{$H$} & \multicolumn{2}{|l|}{$J$} & \multicolumn{2}{|c|}{ Comp } \\
\hline & & $p s F$ & $p$ & $p s F$ & $p$ & $p s F$ & $p$ & $p s F$ & $p$ & $p s F$ & $p$ & $p s F$ & $p$ \\
\hline \multicolumn{14}{|l|}{ Meiofauna } \\
\hline St & 2 & 24.2 & $0.000 * *$ & 21.4 & $0.000 * *$ & 16.3 & $0.000 * *$ & 1.6 & 0.217 & 2.8 & 0.075 & 9.5 & $0.000 * *$ \\
\hline $\mathrm{Se}$ & 3 & 8.6 & $0.001 *$ & 2.3 & 0.099 & 1.7 & 0.201 & 2.5 & 0.087 & 1.6 & 0.221 & 1.9 & $0.02 *$ \\
\hline $\mathrm{St} \times \mathrm{Se}$ & 4 & 2.9 & $0.046^{*}$ & 0.7 & 0.599 & 0.5 & 0.751 & 0.5 & 0.729 & 1.1 & 0.370 & 1.8 & $0.015^{*}$ \\
\hline Res & 20 & & & & & & & & & & & & \\
\hline \multicolumn{14}{|c|}{ Macrofauna } \\
\hline St & 2 & 0.0 & 0.969 & 11.1 & $0.001 * *$ & 115.5 & $0.000 * *$ & 19.1 & $0.000 * *$ & 2.6 & 0.097 & 21.1 & $0.000 * *$ \\
\hline $\mathrm{Se}$ & 3 & 1.0 & 0.389 & 2.7 & 0.072 & 14.3 & $0.000 * *$ & 1.7 & 0.176 & 0.6 & 0.574 & 2.3 & $0.000 * *$ \\
\hline $\mathrm{St} \times \mathrm{Se}$ & 4 & 2.3 & 0.085 & 5.5 & $0.005^{*}$ & 9.3 & $0.000 * *$ & 0.6 & 0.677 & 2.7 & 0.054 & 2.6 & $0.000 * *$ \\
\hline Res & 20 & & & & & & & & & & & & \\
\hline
\end{tabular}

$p s F$ PERMANOVA pseudoF

Significant effects: $* p<0.05 ; * * p<0.001$

the significant interaction between these two factors were identified by PERMANOVA main test (Table 3). However, the post hoc pairwise comparisons showed that the only significant seasonal effects were produced by the very high biomass at station B in August, and the significant differences between August and the other seasons at this station. Also the differences in biomass among stations were significant only in August.

Nematode $I B$ (individual biomass) in samples varied from 0.005 to $25.615 \mu \mathrm{g}$ wet mass, and it differed among groups of samples defined by either station or season (PERMANOVA main test, season: $p s F=5.65, p=001$, station: $\quad p s F=4.11, \quad p=0.012, \quad$ season $\times$ station: $p s F=8.30, p<0.001)$. At station $\mathrm{A}$, nematode $I B$ was significantly higher in May than in the other two seasons $(p<0.001)$. However, at station $\mathrm{B}$, nematodes $I B$ was significantly higher in August (August $\times$ May $p=0.010$, August $\times$ October $\quad p=0.002, \quad$ August $\times$ January $p<0.001)$ than at other seasons. The mean $I B$ at station $\mathrm{C}$ was also the highest in August (Fig. 3); however, this was not a significant difference (August $\times$ May $p=0.217$, August $\times$ October $p=0.203$ ). Moreover, at stations B and $\mathrm{C}$, nematode $I B$ was significantly lower in January than in May or August (station B: January $\times$ May $p=0.029$, January $\times$ August $p<0.001$; station C: January $\times$ May $p=0.010$, January $\times$ August $p<0.001$ ). Harpacticoida IB in all samples varied from 0.031 to $43.892 \mu \mathrm{g}$ wet mass, and it did not differ among stations; however, it differed significantly among seasons (PERMANOVA main test, season: $p s F=48.78, \quad p<0.001$, station: $p s F=2.32$, $p=0.108$, season $\times$ station: $p s F=5.09, p=0.002$ ). At station A, Harpacticoida was noted only in May. At stations $\mathrm{B}$ and $\mathrm{C}$ in May, $I B$ was the highest; however, at station B, it did not differ significantly from that in January and at station $\mathrm{C}$ from that in October. At stations B and C, Harpacticoida $I B$ was significantly lower in August than in other seasons $(p<0.001)$.

Significant differences in meiofauna composition between groups of samples defined by station and season as well as the significant interaction between these two factors were identified by PERMANOVA main test (Table 3). The fauna at station A differed significantly from that at the other two stations in all seasons, while there were no differences between station B and station C. The seasonal contrasts were limited to a significant difference between summer and autumn samples collected at station $C$ (post hoc pairwise PERMANOVA tests). A clear gradual shift in meiobenthic composition from station located in the glacial bay (station A) to stations located in the central basin (stations B, C) was shown on PCO ordination (with $67 \%$ of total variation represented by the first two axes, Fig. 5).

Three variables were statistically significant in DISTLM sequential tests applied for meiofauna community composition: chlorophyll $a$ and POC content in surface sediments and bottom water temperature. However, only the first two factors remained significant in sequential tests (and together explained $72 \%$ of biological variability, Table 5). Regarding the density and taxonomic richness, only bottom water salinity was identified as significant factor in sequential tests (and explained 43 and $63 \%$ of variability, respectively) with POC in sediments identified as a second significant factor for density, but only in marginal tests. 
MEIOFAUNA
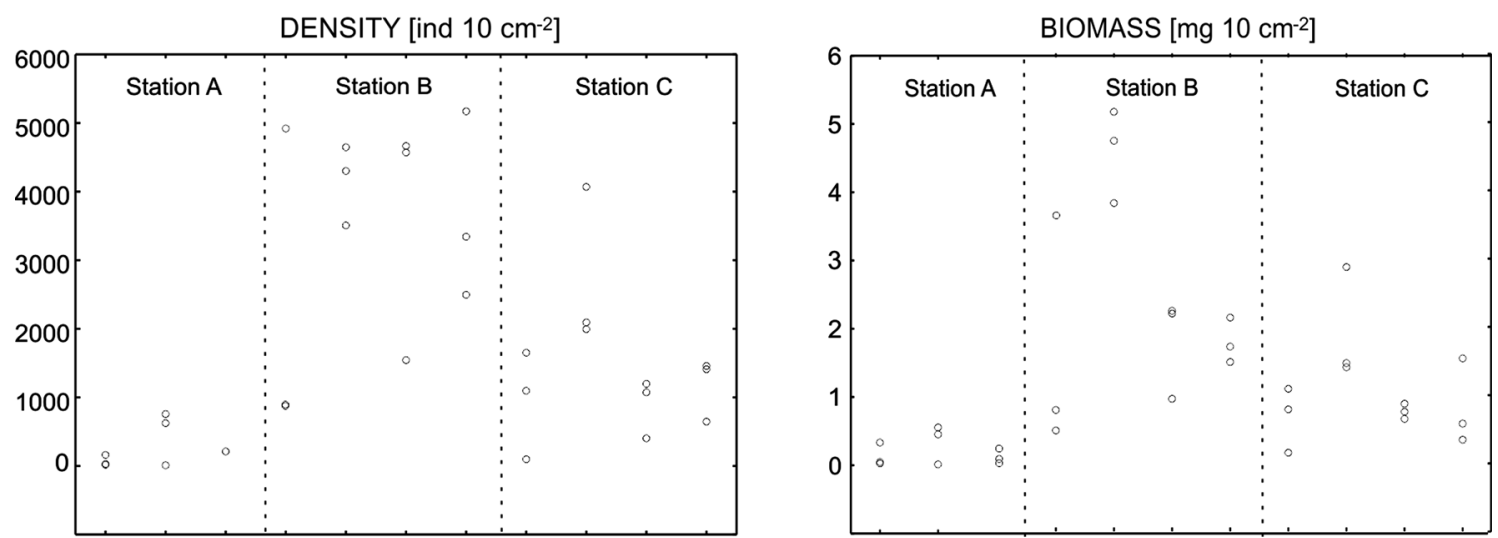

May Aug Oct May Aug Oct Jan May Aug Oct Jan
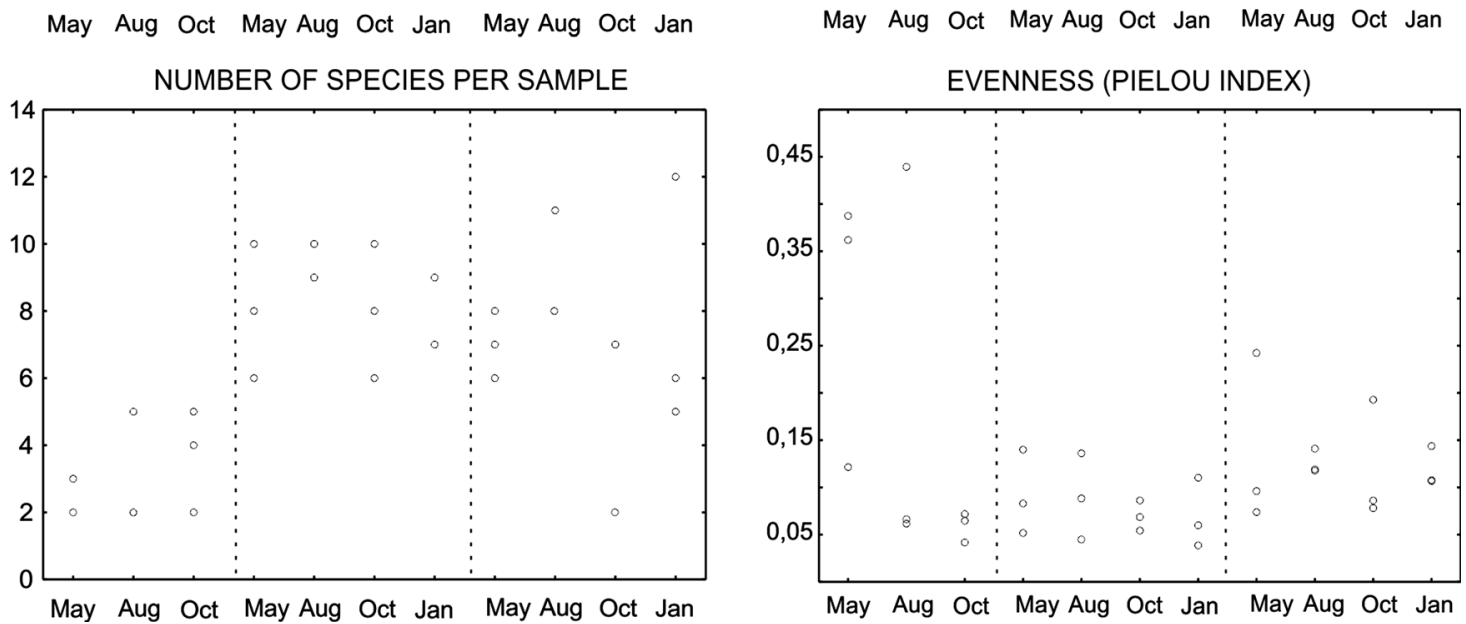

Fig. 2 Meiofauna density (ind. $10 \mathrm{~cm}^{-2}$ ), biomass $\left(\mathrm{mg} 10 \mathrm{~cm}^{-2}\right)$, number of taxa per sample, Shannon-Wiener index of species diversity and Pielou index of evenness in samples collected at three stations and in four seasons (Jan—January, May, Aug—August, Oct—October)

None of the analyzed environmental factors was significantly correlated with variability in meiofaunal biomass.

\section{Macrofauna}

A total of 166 macrofaunal taxa were identified (mostly to species level). The species list included 94 polychaete (Polychaeta), 25 mollusk (Mollusca) and 28 crustacean (Crustacea) taxa. These three taxonomic groups were also the most abundant; polychaetes made $93 \%$ of all individuals, mollusks-4\%, and crustaceans-1\%.

A total of 43 taxa were found in samples collected at station A. Representatives of the two polychaete familiesCirratulidae (with Aphalochaeta sp.-39\%, Chaetozone setosa-3\% and Chaetozone spp-2. \%) and Cossuridae (Cossura longocirrata-26\%)—made almost $70 \%$ of all individuals collected at station A. A bivalve Yoldiella solidula and a polychaete Chone spp. made the further $18 \%$ and occurred at station A with $100 \%$ frequency and with much higher densities (34.5 and 24.3 ind. $0.1 \mathrm{~m}^{-2}$ on average) than at the other two stations (Table 4). A total of 131 and 128 species were present in samples collected at stations B and C, respectively. Lumbrineris spp. was the only species that occurred in all samples at three stations, but attained 10-fold higher numbers at stations $\mathrm{B}$ and $\mathrm{C}$ (about 100 ind. $0.1 \mathrm{~m}^{-2}$ ) than at station A (about 10 ind. $0.1 \mathrm{~m}^{-2}$ ). Prionospio cirrifera, Maldane sarsi, Leitoscoloplos mammosus and Galathowenia oculata dominated the fauna at stations $\mathrm{B}$ and $\mathrm{C}$ in terms of numbers of individuals, while they were absent or occurred only incidentally in samples collected at station A (Table 4).

The macrofaunal density was significantly lower at station A (on average 326 ind. $0.1 \mathrm{~m}^{-2}$ ) than at the other two stations (on average 826 ind. $0.1 \mathrm{~m}^{-2}$, significant contrasts by PERMANOVA main test and post hoc pairwise comparisons, Fig. 4; Table 3). Significant contrasts in the sample species richness among groups of samples defined by station, season and the interaction between the two factors were identified by the PERMANOVA main test 

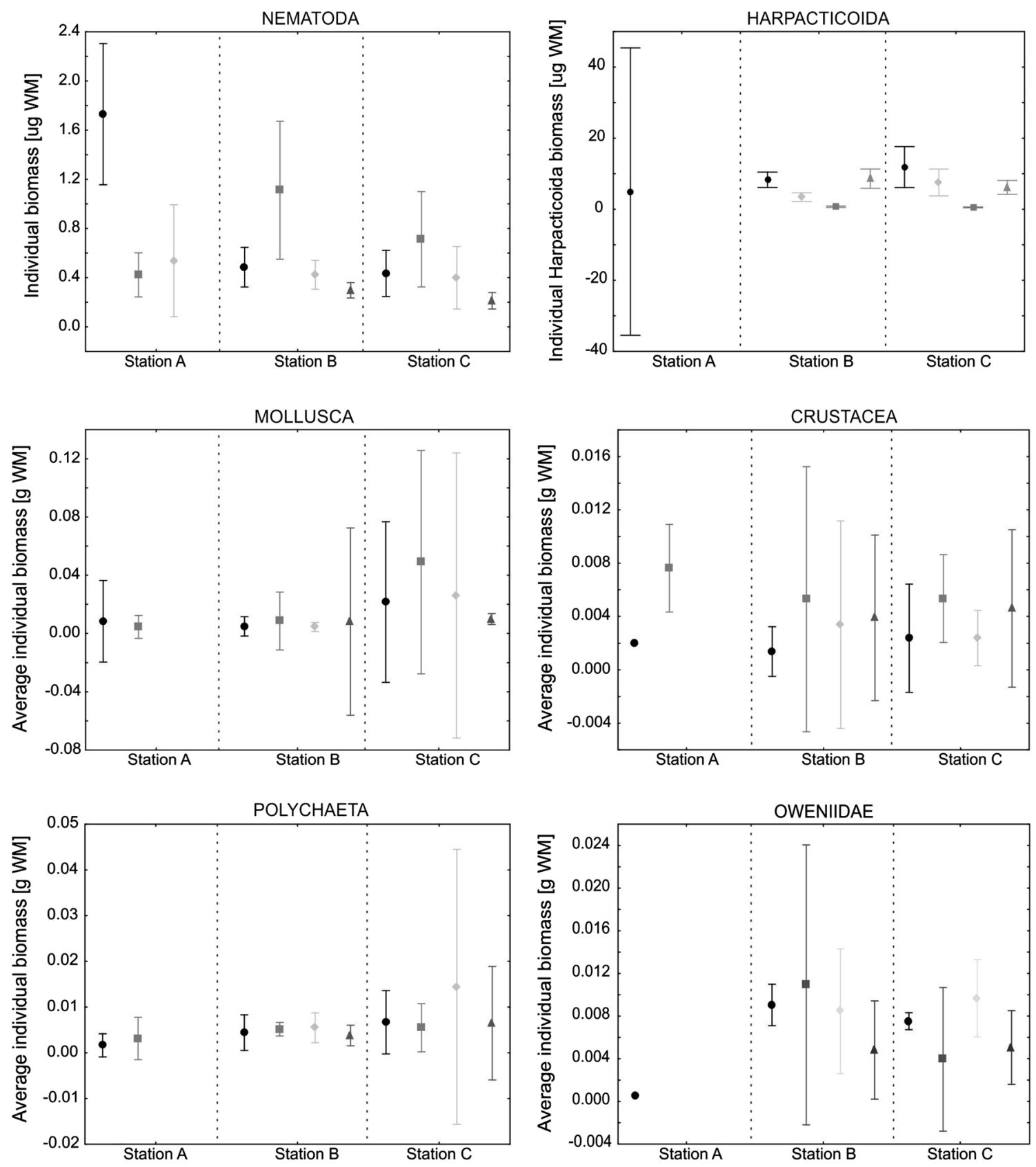

May $=$ August + October $\boldsymbol{\Delta}$ January

Fig. 3 Nematoda and Harpacticoida individual biomass ( $\mu \mathrm{g}$ WM) and Mollusca, Polychaetea, Crustacea and Oweniidae average individual biomass $(\mathrm{g} \mathrm{WM})$ in samples. Mean and $0.95 \%$ confidence interval are presented

(Table 3). Sample species richness was lower at station A (19 species per sample on average) than at the other two stations (52 per sample at station B and 51 per sample at station $\mathrm{C}$ ), and these contrasts were significant regardless of the season. On the other hand, the seasonal effects on the sample species richness were evident only in the increased species richness in August recorded at station C (Fig. 3). No effects of either station or season on macrobenthic evenness (Pielou index) or biomass were detected with use of PERMANOVA tests (Table 3).

Polychaete $A I B$ in samples varied from 1 to $27 \mathrm{mg}$, and it did not differ among groups of samples defined by station or season (PERMANOVA main test Fig. 3). Mollusk AIB did not differ among seasons, but it was significantly higher at station $\mathrm{C}(3-80 \mathrm{mg})$ than at the other two stations (1-21 mg). The higher $A I B$ at station $\mathrm{C}$ resulted from the 
Table 4 Frequency of occurrence $[F(\%)]$, dominance $[D(\%)]$ and average density [avD (ind. $0.1 \mathrm{~m}^{-2}$ )] of dominant macrofaunal taxa in groups of samples collected at the three stations $(\mathrm{A}, \mathrm{B}, \mathrm{C})$

\begin{tabular}{|c|c|c|c|c|c|c|c|c|c|}
\hline \multirow[t]{2}{*}{ Species } & \multicolumn{3}{|c|}{ Station A } & \multicolumn{3}{|c|}{ Station B } & \multicolumn{3}{|c|}{ Station $\mathrm{C}$} \\
\hline & $F$ & $D$ & $a v D$ & $F$ & $D$ & $a v D$ & $F$ & $D$ & $a v D$ \\
\hline Aphalochaeta spp. & 100 & 39 & 127.0 & 8 & 0 & 12.0 & 25 & 0 & 7.3 \\
\hline Cossura longocirrata & 100 & 26 & 85.2 & 58 & 1 & 11.3 & 83 & 2 & 16.3 \\
\hline Chone spp. & 100 & 11 & 34.8 & 83 & 0 & 4.0 & 92 & 1 & 4.5 \\
\hline Yoldiella solidula & 100 & 7 & 24.3 & 25 & 0 & 3.0 & 42 & 0 & 3.2 \\
\hline Lumbrineris spp. & 100 & 3 & 10.0 & 100 & 12 & 113.3 & 100 & 14 & 98.4 \\
\hline Chaetozone setosa & 83 & 3 & 10.8 & 100 & 1 & 6.5 & 100 & 1 & 9.0 \\
\hline Prionospio cirrifera & 17 & 0 & 10.0 & 100 & 36 & 336.3 & 100 & 25 & 176.7 \\
\hline Leitoscoloplos mammosus & - & - & - & 100 & 11 & 107.7 & 100 & 8 & 53.8 \\
\hline Maldane sarsi & - & - & - & 100 & 10 & 91.8 & 100 & 16 & 115.9 \\
\hline Galathowenia oculata & 17 & 0 & 10.0 & 100 & 4 & 33.8 & 100 & 7 & 47.5 \\
\hline Microclymene/Clymenura & - & - & - & 100 & 4 & 36.0 & 92 & 3 & 21.0 \\
\hline
\end{tabular}
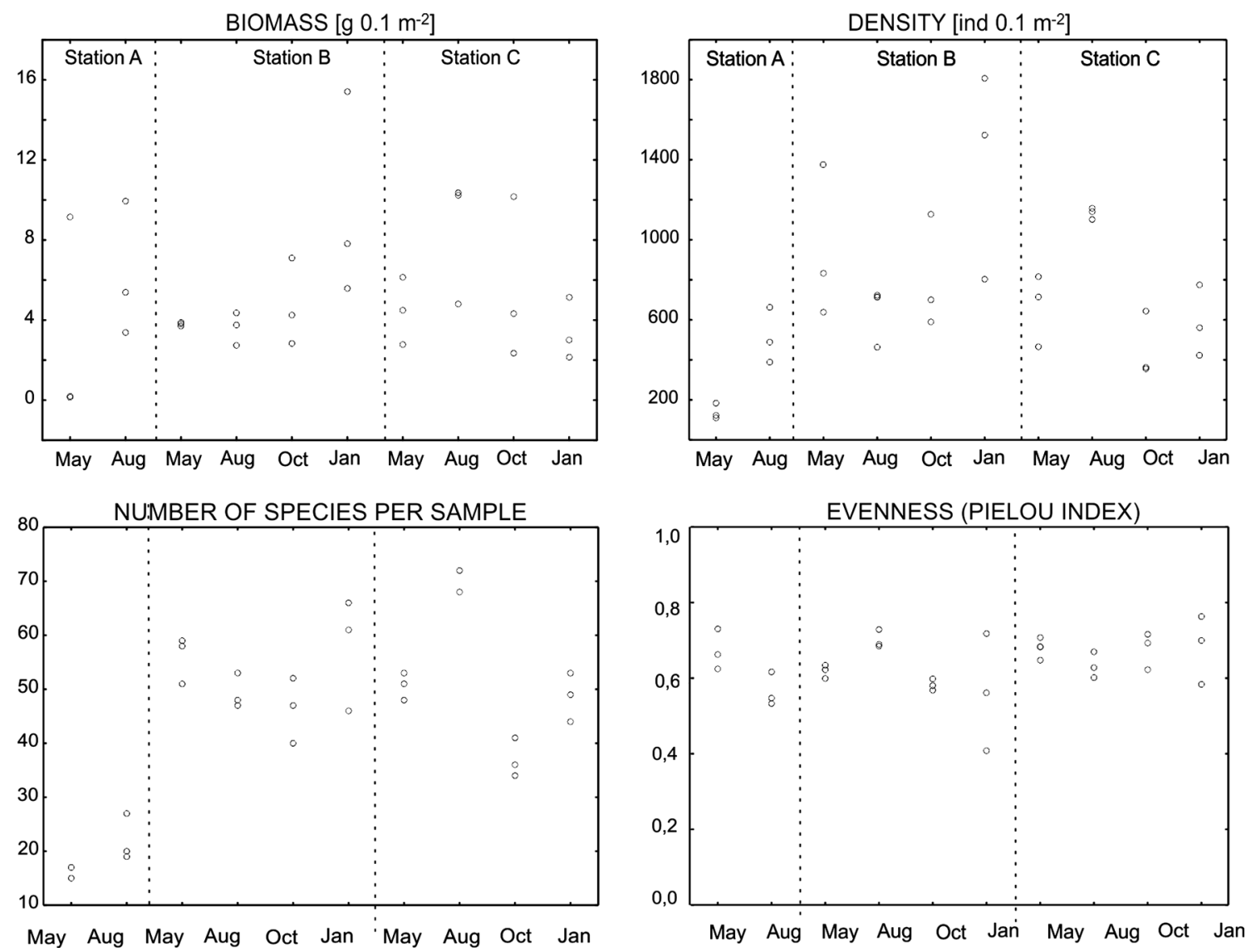

Fig. 4 Macrofauna density (ind. $0.1 \mathrm{~m}^{-2}$ ), biomass $\left(\mathrm{g} 0.1 \mathrm{~m}^{-2}\right.$ ), number of taxa per sample, Shannon-Wiener index of species diversity and Pielou index of evenness in samples collected at three stations and in four seasons (Jan—January, May, Aug-August, Oct-October)

presence of few large specimens of Bathyarca glacialis. For Crustacea, only the season-related differences were observed; the $A I B$ was significantly lower in May (1-4 g) than in January $(2-7 \mathrm{~g})$ or in August (1-9 g). Among the dominant polychaetes families (that were considered for $A I B$ analyses; Cirratulidae with $A I B$ from below 1-13 g,
Lumbrineridae 1-16 g, Sabellidae 1-31 g, Spionidae 1-6 g, Maldanidae 7-29 g), the significant differences related to either station or season were noted only for Oweniidae (PERMANOVA main tests; season: $\mathrm{psF}=3.9$, $p=0.021$, station: $\mathrm{psF}=26.5 p=0.0001$, season $\times$ station: $\mathrm{psF}=3.1 \quad p=0.022$ ). Pairwise tests indicated 
Fig. 5 PCO plots based on Bray-Curtis similarities of meio- and macrofaunal species/taxa abundances in samples. Data were square-roottransformed (for meiofauna also standardized). For macrofauna, a PCO based on only samples collected at stations B and C (encircled on the main PCO plot) is also presented. Symbols represent stations and seasons
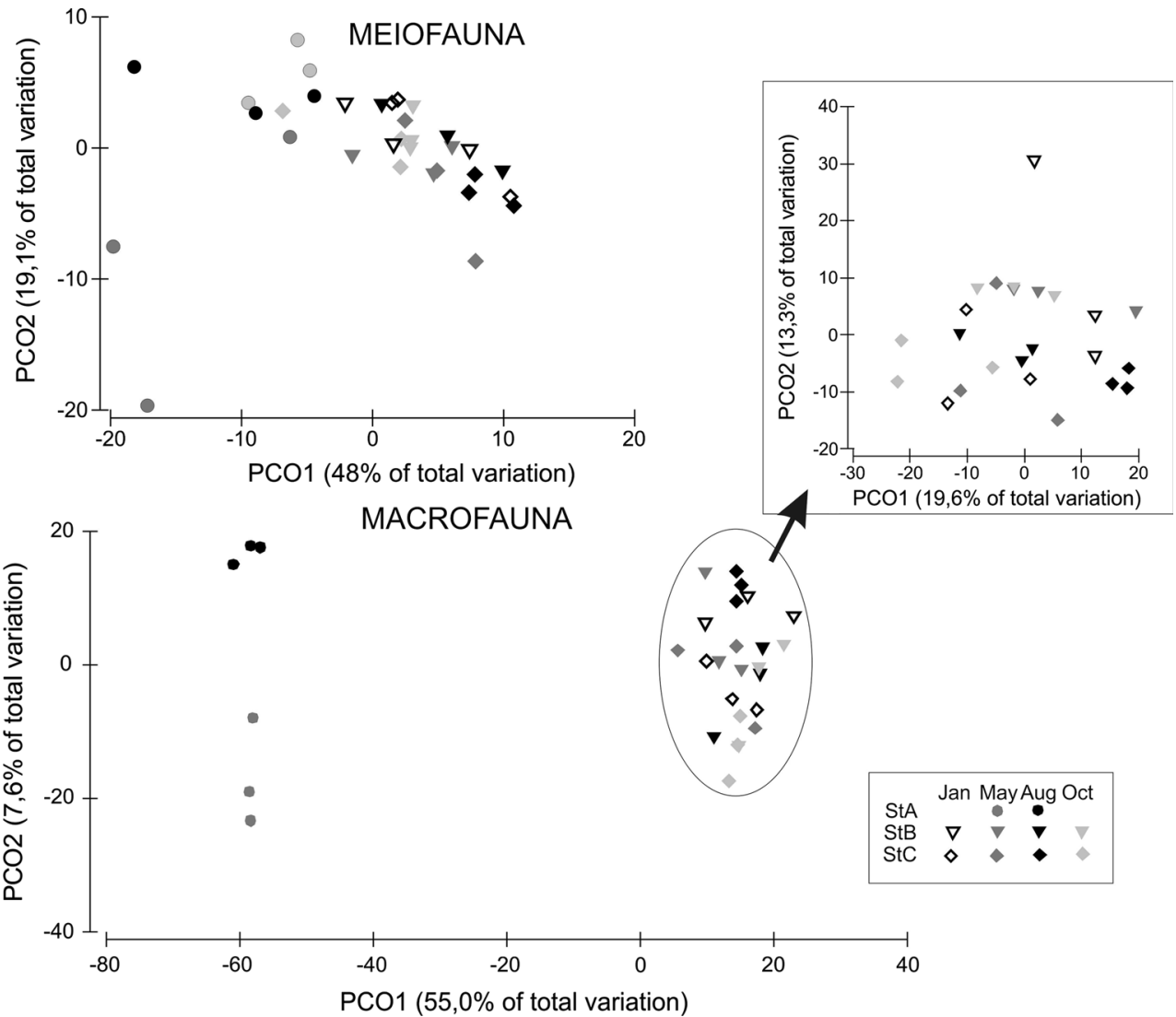

significant contrasts in oweniid $A I B$ between May and January at station B and between May and January and August and October at station C.

Significant differences in macrofaunal composition between groups of samples defined by station and season as well as the significant interaction between these two factors were identified by the PERMANOVA main test (Table 3). However, the only significant seasonal contrasts revealed by post hoc pairwise comparisons were between May and August at station A and between August and October at station C. The post hoc tests performed for pairs of samples defined by station showed that station A was significantly different from other stations in all seasons, while the differences between stations $\mathrm{B}$ and $\mathrm{C}$ differed depending on the season (i.e., significant differences detected only in August). On the PCO ordination, samples collected at station A were clearly separated from those collected at the other two stations (Fig. 5). The samples collected during the two seasons at station A differed, while no effect of seasonality was visible among the samples collected at stations B and C-either on the PCO plotted for the whole material or when only samples from those two stations were used for the analyses (Fig. 5).

POC in surface sediments and total suspended matter in water column were identified by DISTLM marginal tests as significantly related to variability in macrobenthic composition, with only the first one left as significant (and explaining $57 \%$ of biological variability) when forward selection procedure was applied (Table 5). Bottom water salinity and POC in sediments were identified as significantly related to macrobenthic species richness, only salinity (explaining $75 \%$ ) was significant in sequential tests. None of the studied environmental factors was indicated as significant in DISTLM models developed to explain the variability in macrobenthic density and biomass.

\section{Discussion}

\section{Seasonal variability in benthic communities}

No clear, consistent signal of seasonal variability in standing stocks or diversity of meio- or macrobenthic community was noted in the present study. Recently, Berge et al. (2015) reported similar levels of macrobenthic abundance and sediment community respiration rates in deep Kongsfjorden basins in January and other seasons that were characterized by higher supply of organic matter produced in the water column. These observations in the deeper (90-300 m) basins of the fjord agree with the previous report of Kędra et al. (2012) who compared 
Table 5 Results of DISTLM procedure for fitting environmental variables to meio- and macrofaunal community univariate characteristics ( $N$ - density, $S$ number of taxa per sample) and community composition (comp, analyzed with the Bray-Curtis similarities of double-roottransformed data)

\begin{tabular}{|c|c|c|c|c|c|c|c|c|c|c|c|}
\hline \multicolumn{4}{|l|}{ Comp } & \multicolumn{4}{|l|}{$N$} & \multicolumn{4}{|l|}{$S$} \\
\hline Var & $p s F$ & $p$ & $R^{2}$ & Var & $p s F$ & $p$ & $R^{2}$ & Var & $p s F$ & $p$ & $R^{2}$ \\
\hline \multicolumn{12}{|c|}{ Meiofauna } \\
\hline \multicolumn{12}{|c|}{ Marginal tests } \\
\hline Chla & 4.8 & 0.001 & 0.41 & Sal & 5.4 & 0.009 & 0.44 & Sal & 12.2 & 0.006 & 0.63 \\
\hline$P O C$ & 2.9 & 0.017 & 0.30 & $P O C$ & 4.5 & 0.035 & 0.39 & $P O C$ & 6.3 & 0.043 & 0.47 \\
\hline Temp & 2.6 & 0.03 & 0.27 & - & & & & - & & & \\
\hline \multicolumn{12}{|c|}{ Sequential tests } \\
\hline Chla & 4.8 & 0.001 & 0.41 & Sal & 5.4 & 0.014 & 0.44 & Sal & 12.2 & 0.005 & 0.63 \\
\hline$P O C$ & 6.6 & 0.008 & 0.31 & - & & & & - & & & \\
\hline \multicolumn{12}{|c|}{ Macrofauna } \\
\hline \multicolumn{12}{|c|}{ Marginal tests } \\
\hline$P O C$ & 8.2 & 0.025 & 0.58 & - & & & & Sal & 16.4 & 0.009 & 0.73 \\
\hline$T S M$ & 3.7 & 0.025 & 0.38 & - & & & & $P O C$ & 9.9 & 0.029 & 0.62 \\
\hline \multicolumn{12}{|c|}{ Sequential tests } \\
\hline$P O C$ & 8.8 & 0.045 & 0.59 & - & & & & Sal & 16.4 & 0.012 & 0.73 \\
\hline
\end{tabular}

Only significant effects $(p<0.05)$ are presented in table

$p s F$ pseudoF, Chla chlorophyll a concentration in surface sediments, POC particulate organic carbon in surface sediments, TSM total suspended matter, Sal, Temp salinity and temperature of bottom water layers macrobenthic communities dwelling in shallow $(5-25 \mathrm{~m})$ zone of Kongsfjorden soft bottom in winter (March) and summer (August). Kędra et al. (2012) found no significant difference in abundance or biomass, and only slightly lower species richness in the winter season that they attributed to increased disturbance in shallow water produced by ice and storms. Similarly, Echeverria and Paiva (2006) found little variability in macrobenthic community attributes, despite the marked seasonal cycles in pelagic productivity in Antarctic coastal water (Admiralty Bay). For meiofauna, little response in the abundance was recorded after the sedimentation of the spring phytoplankton at the Alaskan shelf by Fleeger et al. (1989) or in a North Water Polynyas by Ambrose and Renaud (1997). On the other hand, Pawłowska et al. (2011) reported a clear signal of increased abundance and biomass of meiofauna and macrofauna after the spring bloom at soft-bottom shallow $(30 \mathrm{~m})$ station located in Adventfjorden, a small basin influenced by a glacial river inflow. Also, Morata et al. (2015) reported that in Rijpfjorden-a fjord located off Nordaustlandet Island (Svalbard Archipelago) - the macrobenthic biomass (at depths below $200 \mathrm{~m}$ ) was lower in winter (January) than that recorded by previous studies performed in the same locality in summer season (Carroll and Ambrose 2012). Macrofauna recovered with winter sediments in Rijpfjorden also responded with a rapid increase in bioturbation activity to experimental addition of food that suggested sensitivity to pulses of fresh phytodetritus, following the spring bloom (Morata et al. 2015).
The absence of a clear response to seasonal variability in organic matter supply in Kongsfjorden may be an effect of the relatively high productivity and resulting year-round high availability of organic carbon in the sediment of this fjord. Mincks et al. (2005) postulated that large input of carbon produced during the polar seasonal bloom together with low rates of bacterial mineralization at low temperatures may results in formation of a 'food bank'-i.e., large reserves of labile organic matter in sediments that can sustain benthic communities at constant levels of abundance and activity on a year-round basis. The 'food bank' hypothesis was supported by the lack of seasonal variability in macrofaunal densities (Glover et al. 2008) and bioturbation activity (McClintic et al. 2008) despite the clear seasonality in pelagial productivity and organic matter fluxes to shelf sediments of West Antarctic Peninsula. The possible 'food bank'-based insensitivity of Kongsfjorden subtidal infaunal benthic communities to seasonal changes in pelagial food supply may also stem from the trophic affinities of the dominant species, especially the numerous subsurface deposit feeding polychaetes that feed on the organic matter stored in deeper sediment layers. Also, Renaud et al. (2015) reported that in Spitsbergen fjords, the macroalgal detritus contributes considerable portion of the diet of macrofaunal species. The supply of organic carbon from the extensive kelp forests on Kongsfjorden shallow banks (Hop et al. 2002) may occur year-round and hinder the dependency of benthic consumers on the seasonal pulses of pelagial phytodetritus. 
The occurrence, timing and magnitude of responses to seasonality in phytodetrital inputs may largely differ among the main benthic compartments. Gooday (2002) reports that microorganisms (bacteria and protozoans) usually show the strongest and rapid responses (increasing both biomass and activity within days of the arrival of organic matter pulses), while population level responses by the metazoans are retarded and more elusive due to slower turnover rate. The metazoan response may also be timelagged due to the stepwise processing of the phytodetritus along the benthic food chains (as suggested for consecutive bacterial and meiofaunal biomass increases after organic matter supply in Mediterranean seagrass systems, Danovaro 1996). In macrofauna, the obvious population responses to food pulses can be even more difficult to detect due to the longer life histories (Gooday 2002) and the longer food chains that link macrofaunal consumers to phytodetritus (e.g., the link through bacteria and meiofauna proposed by Ambrose and Renaud 1997). Drazen et al. (1998) report that peak of macrofaunal densities occurred about 8 months after peaks of maximal organic matter flux and sediment community oxygen respiration at the abyssal plain in northeast Pacific. Thus, even if occurring, the metazoan response to phytodetritus pulse can be difficult to record by the discrete sampling in the present study that consisted of only four sampling occasions.

\section{Seasonal signals in benthic organism size}

In North Atlantic marine systems, seasonality in invertebrate populations results from the link between seasonal peaks in reproductive intensity or seasonal recruitment and spring/early summer inputs of phytodetritus (e.g., Gooday 2002). Pulsed food inputs can trigger a number of reproductive processes: initiation of gametogenesis, development of gametes, spawning and larval settlement. Eckelbarger and Watling (1995) pointed to the primary role of phylogeny in determining temporal patterns of benthic invertebrate reproduction and proposed several possible reproductive responses to pulsed food inputs including spawning soon after phytodetrital inputs (e.g., in opportunistic polychaetes) or larval ontogeny timed to coincide with seasonal inputs (species with planktotrophic larvae). A possible link between life cycles and spring pulse of fresh organic matter supply was suggested by the seasonal changes in individual biomass of dominant meiofaunal groups (Nematoda, Harpacticoida) in the present study. In the outer basin, nematode individual size attained maximum values in summer (August) and declined in autumn (October). Similar changes of nematode body size were observed by Soltwedel et al. (1996) in deep Greenland Sea. They documented increase in nematode body length and volume from spring to summer and speculated that nematodes grow in size during spring and early summer and reproduce in late summer and after the death of the adults, the populations are dominated by small individuals in September. The seasonal variability in Harpacticoida, the second dominant meiofaunal taxon, was different, and the average size declined from spring and summer to autumn and again rose in winter (January). This difference in time lag between the fresh food input and recruitment of the new generations may be related to different reproductive cycle employed by the two groups (including the larval stage in harpacticoids as opposed to direct brooding by nematodes, Dahms and Qian 2004).

The macrofaunal taxa demonstrated almost no seasonal variability in average individual size. The significant effects (declines in spring) were noted for Crustacea. The seasonal cycles of benthic crustaceans in Spitsbergen fjords are described by Węsławski and Legeżyńska (2002) who reported the incubation of eggs during winter and hatching period indicated the occurrence of the smallest individuals in spring and/or early summer. The average size of mollusks, polychaetes and dominant polychaete families (with exception of Oweniidae) remained constant throughout the year. The decline in oweniid size in May (station B) and August (station C) may also be related to the oweniid life cycle with maximum of larval occurrence in Arctic waters in spring (Fetzer and Arntz 2008) and recruitment of juvenile forms soon after. Kukliński et al. (2013) who studied the occurrence and abundance of benthic larvae in water column as well as the timing of recruitment in a yearround study in Adventfjorden reported that in general, the benthic larvae were not synchronized in their occurrence in their response to organic matter production peaks in the water column, and benthic recruitment was observed yearround with some groups (e.g., spirorbid polychaetes) recruiting preferably in winter season (Kukliński et al. 2013). Ambrose and Renaud (1997) found no obvious link between phytodetrital pulses and recruitment of polychaete species in the northwest polynyas. The relative independence of reproductive cycles of Arctic benthic infaunal species from the seasonality in pelagic production, as suggested previously, may be related to feeding on subsurface reserves of organic carbon rather than fresh carbon accumulating on the seabed (Eckelbarger and Watling 1995) and to lecithotrophy employed by a large number of Arctic benthic invertebrates (Fetzer and Arntz 2008). A trend of relatively rare employment of planktotrophy in Arctic benthic species (as compared to lower latitudes) has been recognized as the mechanism to avoid the consequences of the miss-match between the larval dispersal and short period of intensive pelagial production in polar regions (Fetzer and Arntz 2008). 


\section{Spatial patterns in fjordic benthos}

The elusive seasonal variability in benthic community attributes in Kongsfjorden contrasts with clearly defined and seasonally stable spatial patterns. The fauna dwelling in inner basin (station A) differs sharply from the one in the central/outer basins (station B, C) in terms of univariate (standing stocks, diversity) and multivariate (species composition) characteristics. The faunal impoverishment in inner basins in Kongsfjorden and other west Spitsbergen glacial fjords has been hitherto documented in a number of benthic studies [e.g., Włodarska-Kowalczuk et al. (2005, 2012); Kędra 2010 for macrofauna, WłodarskaKowalczuk et al. (2007); Sommerfield et al. (2006) for meiofauna and macrofauna, Włodarska-Kowalczuk et al. (2013) for macrofauna and Foraminifera]. It is related to high intensity of physical disturbance coupled with low food availability that results from tidal glacier activity which together induces reduced growth rates of populations, elimination of sensitive species and declines in diversity. The lower food availability for benthic consumers in inner basins is an effect of the dilution of organic matter in a large bulk of mineral material and is evidenced in lower concentrations of organic carbon and photosynthetic pigments in sediments (Włodarska-Kowalczuk and Pearson 2004; Kędra et al. 2010; Kuliński et al. 2014) in the inner basin compared to those from the outer fjord. The physical disturbance is produced by the high rates of deposition of glacial transported sediments and unstable fluid sediments that are also occasionally resuspended and/or redeposited by erosional depositional events and iceberg scoring (Włodarska-Kowalczuk and Pearson 2004; Zajaczkowski and Wlodarska-Kowalczuk 2007). High sedimentation is destructive to benthic fauna because it buries larvae and adult animals, impedes animals from maintaining the optimum position in the sediment and clogs feeding and respiratory organs of macrobenthic animals, especially filter feeders (Ahrens and Morrisey 2005).

The glacial impacts within the inner basin are evident in the taxonomic composition of benthic communities. Fauna at station $\mathrm{A}$ is dominated by cirratulid (Cirratulidae) and cossurid (Cossuridae) polychaetes and protobranch bivalves; these small mobile invertebrates are able to selectively feed on detritus particles and are resistant to sediment instabilities and mineral material sedimentation (Włodarska-Kowalczuk and Pearson 2004). The tubedwelling, sedentary fauna is eliminated from the glacial bays as they can be buried by redeposited sediments, thereby impeding tube irrigation and leading to suffocation. In the outer basin (stations B, C), the complex community comprises taxa that represent a wider range of functional traits and lifestyles. This shift in dominants (from cirratulids/corruids/yoldiids toward a complex community including maldanids (Maldanidae) and spionids (Spionidae), tube-dwelling polychaetes penetrating deeper sediment layers) is reported in previous research that covered a wider set of stations in these basins (WlodarskaKowalczuk and Pearson 2004; Kędra et al. 2010). The meiofaunal community of inner basin station A was strongly dominated by Nematoda with few representatives of other groups, similar to other Arctic sites located close to glacial or glaciofluvial inflows (e.g., WłodarskaKowalczuk et al. 2007). Nematoda includes a wide range of morphological and functional forms and is often regarded as resistant (as a group) to disturbances of various nature and origin (Wieser et al. 1974). Experimental studies showed that nematodes are able to actively migrate through interstitial spaces in deeper sediment layers and in this way withstand high sedimentation and burial by deposited mineral materials (Schratzberger et al. 2000). In the present study, the DISTLM analyses identified POC (an indicator of the organic matter availability) and salinity (a proxy of the distance to the glacier outflows), as the significant drivers of benthic patterns, that further supports previous interpretations of processes responsible for faunal impoverishment in glacial fjords.

\section{Conclusions}

The relative resilience of benthic fauna to marked seasonal cycles of pelagic phytodetritus fluxes supports the 'Food bank hypothesis' (Mincks et al. 2005; Glover et al. 2008) and recognition of fjordic environments as sinks of organic matter. A recent report by Smith et al. (2015) reports a very high rate of burial of organic matter in fjordic sediments compared to other marine sedimentary systems, which suggests that carbon reserves stored in fjordic sediments largely exceed benthic community carbon demands. The inclusion of macroalgal carbon into the diet and employment of lecithotrophic larva in life cycles may further release the links between pelagial productivity and benthic seasonality. Our study failed to document a consistent benthic response to spring pelagial phytodetritus flux, but some observations point to possible links specific for certain groups or taxa (nematodes, owenid polychaetes, harpacticoids, macrofaunal crustaceans). Further studies that include observations performed with higher temporal resolution, identification of trophic preferences of various community components, recognition of the details of the life cycles of benthic species (including timing of larval dispersal and recruitment and trophic requirements of benthic larvae), as well as interactions among the species and taxonomic/ecological groups are needed if we are to fully understand the seasonality in Arctic benthic systems. 
Acknowledgments The authors want to thank S. Bourgeois, M. Calleja Cortés, E. Courtecuisse, R. Corvaisier, C. Gueguen, P. Kerhervé, J. Richard and all ECOTAB and Marine Night participants for their help with field sampling and data sharing. We thank the crew of the MS Teistein and R/V Helmer Hanssen and the AWIPEV personnel in Ny-Ålesund for dedicated, professional assistance. We are also grateful to Mrs Małgorzata Geringer d'Oedenberg for Polychaeta identifications. The manuscript benefited from constructive critical comments by prof. Howard Feder and an anonymous reviewer. This study was made possible by funding from the 'Agence Nationale de Recherche' (ECOTAB ANR-11-PDOC-0018-01 to NM), the 'Laboratoire d'Excellence LabexMER' co-funded by a grant from the French government under the program Investissements d'Avenir (ICAR ANR-10-LABX-19 to NM), IPEV and AWIPEV, and the Norwegian Arctic Field Grant and Norwegian Council (WINBA and Marine Night, NRC 226417). The study was also financed by funds provided for IO PAN for the period 2013-2016 for the co-funded international collaborative research based on the contract no. 2930/Norway/2013/2. MWK, BG and KD were supported by the Institute of Oceanology Polish Academy of Sciences, National Science Centre grant No. DEC-2012/05/B/NZ8/02654 (BIOSIZE) and the funds of the Leading National Research Centre (KNOW) received by the Centre for Polar Studies for the period 2014-2018. This work is a contribution to the ANR-ECOTAB, ICAR, Marine Night and WINBA projects and to the Arctos Network.

Open Access This article is distributed under the terms of the Creative Commons Attribution 4.0 International License (http://creative commons.org/licenses/by/4.0/), which permits unrestricted use, distribution, and reproduction in any medium, provided you give appropriate credit to the original author(s) and the source, provide a link to the Creative Commons license, and indicate if changes were made.

\section{References}

Ahrens MJ, Morrisey DJ (2005) Biological effects of unburnt coal in the marine environment. Oceanogr Mar Biol 43:69-122

Aller JY, Stupakoff I (1996) The distribution and seasonal characteristics of benthic communities on the Amazon shelf as indicators of physical processes. Cont Shelf Res 16:717-751

Ambrose WG Jr, Renaud PE (1997) Does a pulsed food supply to the benthos affect polychaete recruitment patterns in the Northeast Water Polynya? J Mar Syst 10:483-495

Anderson MJ, Gorley RN, Clarke KR (2008) PERMANOVA for PRIMER: guide to software and statistical methods. PRIMER-E Ltd., Plymouth

Andrassy I (1956) The determination of volume and weight of nematodes. Acta Zool Acad Sci Hung 2:1-15

Austen MC, Warwick RM, Rosado MC (1989) Meiobenthic and macrobenthic community structure along a putative pollution gradient in southern Portugal. Mar Pollut Bull 20:398-405

Berge J, Daase M, Renaud PE, Ambrose WG, Darnis G, Last KS, Leu E, Cohen JH, Johnsen G, Moline MA, Cottier F, Varpe $\varnothing$, Shunatova N, Bałazy P, Morata N, Massabuau J-C, FalkPetersen S, Kosobokova K, Hoppe CJM, Węsławski JM, Kukliński P, Legeżyńska J, Nikishina D, Cusa M, Kędra M, Włodarska-Kowalczuk M, Vogedes D, Camus L, Tran D, Michaud E, Gabrielsen TM, Granovitch A, Gonchar A, Krapp R, Callesen TA (2015) Unexpected levels of biological activity during the polar night offer new perspectives on a warming Arctic. Curr Biol 25:2555-25611

Carroll ML, Ambrose WGJ (2012) Benthic infaunal community variability on the Northern Svalbard Shelf. Polar Biol $35: 1259-1272$
Cottier FR, Nilsen F, Inall ME, Gerland S, Tverberg V, Svendsen H (2007) Wintertime warming of Arctic shelves in response to large-scale atmospheric circulation. Geophys Res Lett 34:L10607

Dahms HU, Qian PY (2004) Life histories of the Harpacticoida (Copepoda, Crustacea): a comparison with meiofauna and macrofauna. J Nat Hist 38:1725-1734

Danovaro R (1996) Detritus-bacteria-meiofauna interaction in a seagrass bed (Posidonia oceanica) of the $\mathrm{N}-\mathrm{W}$ Mediterranean. Mar Biol 127:1-13

Drazen JE, Baldwin RJ, Smith KL (1998) Sediment community response to a temporally varying food supply at an abyssal station in the NE Pacific. Deep-Sea Res II 45:893-913

Echeverria C, Paiva PC (2006) Macrofaunal shallow benthic communities along a discontinuous annual cycle at Admiralty Bay, King George island, Antarctic. Polar Biol 29:263-269

Eckelbarger KJ, Watling L (1995) Role of phylogenetic constraints in determining reproductive patterns in deep sea invertebrates. Invert Biol 114:256-269

Feller RJ, Warwick RM (1988) Energetics. In: Higgins RP, Thiel H (eds) Introduction to the study of meiofauna. Smithsonian Institution Press, Washington, pp 181-196

Fetzer I, Arntz WE (2008) Reproductive strategies of benthic invertebratesin the Kara Sea (Russian Arctic): adaptation of reproduction modes to cold water. Mar Ecol Prog Ser 356:189-202

Fleeger JW, Shirley TC, Ziemann DA (1989) Meiofaunal responses to sedimentation from an Alaskan spring bloom I. Major taxa. Mar Ecol Prog Ser 51:131-145

Glover AG, Smith CR, Mincks SL, Sumida PYG, Thurber AR (2008) Macrofaunal abundance and composition on the West Antarctic Peninsula continental shelf: evidence for a sediment 'food bank' and similarities to deep-sea habitats. Deep-Sea Res II $55: 2491-2501$

Gooday AJ (2002) Biological responses to seasonally varying fluxes of organic matter to the ocean floor: a review. J Oceanogr $58: 305-332$

Grebmeier JM, McRoy P, Feder HM (1988) Pelagic-benthic coupling on the shelf of the northern Bering and Chukchi Seas. I. Food supply source and benthic biomass. Mar Ecol Prog Ser 48:57-67

Heip C, Vincx M, Vranken G (1985) The ecology of marine nematodes. Oceanogr Mar Biol Ann Rev 23:399-489

Hop H, Pearson T, Hegset EH, Kovacs K, Wiencke C, Kwaśniewski S, Eiane K, Mehlum F, Gulliksen F, Włodarska-Kowalczuk M, Lydersen C, Węsławski JM, Cochrane S, Gabrielsen GW, Leakey R, Lonne OJ, Zajączkowski M, Falk-Petersen S, Kendall M, Wangberg SA, Bishof K, Voronkov AY, Kovaltchuk N, Wiktor J, Plterman M, Di Prisco G, Estopey A, Papucci C, Gerland S, Lipertt H (2002) The ecosystem of Kongsfjorden, Svalbard. Polar Res 24:113-121

Juul-Pedersen T, Michel C, Gosselin M (2008) Seasonal changes in the sinking export of particulate material, under first-year sea ice on the Mackenzie Shelf (western Canadian Arctic). Mar Ecol Prog Ser 353:13-25

Kędra M, Włodarska-Kowalczuk M, Węsławski JM (2010) Decadal change in macrobenthic soft-bottom community structure in a high Arctic fjord (Kongsfjorden, Svalbard). Polar Biol 33:1-13

Kędra M, Kuliński K, Walkusz W, Legeżyńska J (2012) The shallow benthic food web structure in the high Arctic does not follow seasonal changes in the surrounding environment. Estuar Coast Shelf Sci 114:183-191

Kukliński P, Berge J, McFadden L, Dmoch K, Zajaczkowski M, NygÅrd H, Piwosz K, Tatarek A (2013) Seasonality of occurrence and recruitment of Arctic benthic marine invertebrates larvae in relation to environmental variables. Polar Biol 36:549-560 
Kuliński K, Kędra M, Legeżyńska J, Głuchowska M, Zaborska A (2014) Particulate organic matter sinks and sources in high Arctic fjord. J Mar Syst 139:27-37

Link H, Archambault P, Tamelander T, Renaud PE, Piepenburg D (2011) Spring-to-summer changes and regional variability of benthic processes in the western Canadian Arctic. Polar Biol 34:2025-2038

Mazurkiewicz M, Gorska B, Jankowska E, Włodarska-Kowalczuk M (in press) Assessment of nematode biomass in marine sediments: a semi-automated image analysis method. Limnol Oceanogr Methods

McClintic MA, DeMaster DJ, Thomas CJ, Smith CR (2008) Testing the FOODBANCS hypothesis: seasonal variations in nearbottom particle flux, bioturbation intensity, and deposit feeding based on 234 Th measurements. Deep-Sea Res II 55:2425-2437

Mincks SL, Smith CR, deMaster DJ (2005) Persistence of labile organic matter and microbial biomass in Antarctic shelf sediments: evidence of a sediment 'food bank'. Mar Ecol Prog Ser 300:3-19

Morata N, Michaud E, Włodarska-Kowalczuk M (2015) Impact of early food input on the Arctic benthos activities during the polar night. Polar Biol 38:99-114

Pawłowska J, Włodarska-Kowalczuk M, Zajączkowski M, Nygård H, Berge J (2011) Seasonal variability of meio- and macrobenthic standing stocks and diversity in an Arctic fjord (Adventfjorden, Spitsbergen). Polar Biol 34:833-845

Piepenburg D, Blackburn TH, von Dorrien CF, Gutt J, Hall POJ, Hulth S, Kendall MA, Opaliński KW, Rachor E, Schmidt MK (1995) Partitioning of benthic community respiration in Arctic (northwestern Barents Sea). Mar Ecol Prog Ser 18:199-213

Reigstad M, Riser CW, Wassmann P, Ratkova T (2008) Vertical export of particulate organic carbon: attenuation, composition and loss rates in the northern Barents Sea. Deep-Sea Res II 55:2308-2319

Renaud PE, Riedel A, Michel C, Morata N, Gosselin M, JuulPedersen T, Chiuchiolo A (2007) Seasonal variation in benthic community oxygen demand: a response to an ice algal bloom in the Beaufort Sea, Canadian Arctic? J Mar Syst 67:1-12

Renaud PE, Morata N, Carroll ML, Denisenko SG, Reigstad M (2008) Pelagic-benthic coupling in the western Barents Sea: processes and time scales. Deep-Sea Res II 55:2372-2380

Renaud PE, Løkken TS, Jørgensen LL, Berge J, Johnson BJ (2015) Macroalgal detritus and food-web subsidies along an Arctic fjord depth gradient. Front Mar Sci 2:31

Rysgaard S, Thamdrup B, Risgaard-Petersen N, Fossing H, Berg P, Bondo PB, Dalsgaard T (1998) Seasonal carbon and nutrient remineralization in a high-Arctic coastal marine sediment. Mar Ecol Prog Ser 175:261-276

Schratzberger M, Rees HL, Boyd SE (2000) Effects of simulated deposition of dredged material on structure of nematode assemblages - the role of burial. Mar Biol 136:519-530

Smith RW, Bianchi TS, Alison M, Savage C, Galy V (2015) High rates of organic carbon burial in fjord sediments globally. Nat Geosci 8:450-453

Soltwedel T, Pfannkuche O, Thiel H (1996) The size-structure of deep-sea meiobenthos in the north-eastern Atlantic: nematodes size spectra in relation to environmental variables. J Mar Biol Assoc UK 76:327-344
Sommerfield PJ, Cochrane SJ, Dahle S, Pearson TH (2006) Freeliving nematodes and macrobenthos in a high-latitude glacial fjord. J Exp Mar Biol Ecol 330:284-296

Søreide JE, Carroll ML, Hop H, Ambrose WG, Hegseth EN, FalkPetersen S (2013) Sympagic-pelagic-benthic coupling in Arctic and Atlantic waters around Svalbard revealed by stable isotopic and fatty acid tracers. Mar Biol Res 9:831-850

Svendsen H, Beszczyńska-Møller A, Hagen JO, Lefauconnier B, Tverberg V, Gerland S, Ørbæk JB, Bischof K, Papucci C, Zajączkowski M, Azzolini R, Bruland O, Wiencke Ch, Winther JG, Dallmann W (2002) Physical Kongsfjord environment overview paper. Polar Res 21:133-166

Warwick RM, Platt HM, Clarke KR, Agard J, Gobin J (1990) Analyses of macrobenthic and meiobenthic community structure in relation to pollution and disturbance in Hamilton harbour, Bermuda. J Exp Mar Biol Ecol 138:119-142

Wassmann P, Reigstad M (2011) Future Arctic Ocean seasonal ice zones and implications for pelagic-benthic coupling. Oceanography $24: 220-231$

Węsławski JM, Legeżyńska J (2002) Life cycles of some Arctic amphipods. Pol Polar Res 23:253-264

Wieser W, Ott J, Schiemer F, Gnaiger E (1974) An ecophysiological study of some meiofauna species inhabiting a sandy beach at Bermuda. Mar Biol 26:235-248

Włodarska-Kowalczuk M, Pearson T (2004) Soft-bottom macrobenthic faunal associations and factors affecting species distributions in an Arctic glacial fjord (Kongsfjord, Spitsbergen). Polar Biol 27:155-167

Włodarska-Kowalczuk M, Pearson TH, Kendall MA (2005) Benthic response to chronic natural physical disturbance by glacial sedimentation in an Arctic fiord. Mar Ecol Prog Ser 303:31-41

Włodarska-Kowalczuk M, Szymelfenig M, Zajączkowski M (2007) Dynamic sedimentary environments of an Arctic glacier-fed river estuary (Adventfjorden, Svalbard). II. Meio- and macrobenthic fauna. Estuar Coast Shelf Sci 74:274-284

Włodarska-Kowalczuk M, Renaud PE, Węsławski JM, Cochrane SKJ, Denisenko SG (2012) Species diversity, functional complexity and rarity in arctic fjordic versus open shelf benthic system. Mar Ecol Prog Ser 463:73-87

Włodarska-Kowalczuk M, Pawłowska J, Zajączkowski M (2013) Do foraminifera mirror diversity and distribution patterns of macrobenthic fauna in an Arctic glacial fjord? Mar Micropaleontol 103:30-39

Lalande C, Moriceau B, Leynaert A, Morata N (2016) Spatial and temporal variability in export fluxes of biogenic matter in Kongsfjorden. Polar Biol. doi:10.1007/s00300-016-1903-4

Zajączkowski M (2008) Sediment supply and fluxes in glacial and outwash fjords: Kongsfjorden and Adventfjorden, Svalbard. Pol Polar Res 29:59-72

Zajaczkowski M, Włodarska-Kowalczuk M (2007) Dynamic sedimentary environments of an Arctic glacier-fed river estuary (Adventfjorden, Svalbard). I. Flux, deposition and dynamics of the sediment. Estuar Coast Shelf Sci 74:285-296

Zajączkowski M, Nygård H, Hegseth EN, Berge J (2010) Vertical flux of particulate matter in an Arctic fjord: the case of lack of the sea-ice cover in Adventfjorden 2006-2007. Polar Biol $33: 223-239$ 